\title{
SURVEY FOR PSORALEA HYPOGAEA
}

IN THE GREAT FALLS RESOURCE AREA, LEWISTOWN DISTRICT BUREAU OF LAND MANAGEMENT, MONTANA

\author{
Prepared by: \\ Bonnie L. Heidel \\ Montana Natural Heritage Program \\ state Library \\ 1515 E. 6th Avenue \\ P.O. Box 201800 \\ Helena, MT 59620-1800 \\ Prepared for: \\ Bureau of Land Management \\ 81214 th Street North \\ Great Falls, MT 59401
}

Agreement No. 1422-E950-A1-0006, Task order No. 25 


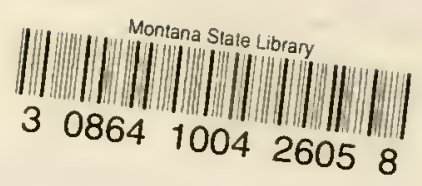

(c) 1994 Montana Natural Heritage Program

This report is to be cited as follows:

Heidel, B. L. 1994. Survey for Psoralea hypogaea in the Great Falls Resource Area, Lewistown District, Bureau of Land

Management, Montana. Montana Natural Heritage Program, Helena. 22 pp. plus appendices. 


\section{TABLE OF CONTENTS}

I. Summary . . . . . . . . . . . . . . . . . . 1

II. Introduction . . . . . . . . . . . . . . . . . . 2

III. Study methods . . . . . . . . . . . . . . . . . 3

IV. Results... . . . . . . . . . . . . . . . . . 7

Sensitive species information

1. Psoralea hypogaea . . . . . . . . . . . . . . 8

2. Carex crawei .. . . . . . . . . . . . . 15

3. Eleocharis compressa . . . . . . . . . 20

v. Recommendations and conclusions . . . . . . . . . 21

VI. Literature cited . . . . . . . . . . . . 22

Appendix 1. Printouts of previous records for plant species of special concern from low elevations within the Great Falls

Resource Area

Appendix 2. Printouts of Psoralea hypogaea in Montana

Appendix 3. Printouts of Carex crawei in Montana

Appendix 4. Natural areas data for BLM Tract \#22 and surrounding chestnut Valley sandhills (includes site map + Figures 4-6 below)

\section{TABLES AND FIGURES}

Table 1. BLM scattered tracts - Great Falls Resource Area . . 5 Table 2. Special status plants - Great Falls Resource Area . 6 Figure 1. Psoralea hypoqaea, close-up . . . . . . . . . 10 Figure 2. Psoralea hypogaea, habitat . . . . . . . . 10 Figure 3. Carex crawei, close-up . . . . . . . . . . . 17 Figure 4. BLM Tract \#22, general aspect.......... App. 4 Figure 5. BLM Tract \#22, sand prairie habitat. . . . App. 4 Figure 6. BLM Tract \#2, wetland habitat......... App. 4 


\section{SUMMARY}

Twenty-six scattered tracts administered by the Bureau of Land Management (BLM) in the Great Falls Resource Area of Montana were reviewed for little indian breadroot (Psoralea hypogaea) potential habitat. Little indian breadroot is the only proposed sensitive plant species known in the resource area (USDI Bureau of Land Management 1993). Thirteen of the tracts were targeted for field inventory. While intact natural habitat was present to varying degrees on each tract, none provided the extremely sandy conditions needed by this proposed sensitive species. However, little indian breadroot was discovered directly outside of a BLM tract (Tract \#22) on private land that may be part of a pasture rotation involving the BLM tract.

In addition, BLM Tract \#22 was found to harbor one other species of special concern in Montana, Craw's sedge (Carex crawei), which is recommended for consideration on the BLM sensitive plant list for the Lewistown District. It is tracked as a species of special concern in Montana (Heidel and Poole 1993) and is documented at five other locations in the state. In the very same habitat on BLM tract \#22, a spikerush was collected and identified as flat-stemmed spikerush (Eleocharis compressa), reported for the first time in Montana. Unresolved taxonomic questions preclude adding it to the state list of plant species of special concern, or recommending it for addition to the Bureau of Land Management sensitive plant list.

Information is presented for little indian breadroot and Craw's sedge on their current status, description, distribution, habitat, population biology, and reproductive biology. The taxonomic questions associated with Eleocharis compressa are described in detail.

In double-checking herbarium records of little indian breadroot, it was determined that little indian breadroot has been collected on or near the BLM Havre Resource Area of the Lewiston District. For this reason, it is recommended for retention as a BLM potential sensitive species in the Lewiston District.

The three main parts of the report include:

1) Information on the survey study,

2) Statewide status reports on little indian breadroot and Craw's sedge, and

3) Detailed description of BLM Tract \#22 and contiguous private land harboring Psoralea hypogaea (Appendix 4). 


\section{INTRODUCTION}

This report describes a botanical survey of Bureau of Land Management (BLM) scattered holdings in Cascade and Lewis and Clark counties, Montana. The purpose of this study was to locate and survey populations of potential sensitive or watch species as proposed by the Bureau of Land Management in Montana (USDI Bureau of Land Management 1993). These are taxa identified by the state office of the Bureau of Land Management as warranting sensitive or watch designation based on global rarity, state rarity, and threats.

Surveys to determine the location and size of rare species populations are being conducted on public lands throughout the west as a result of the Federal Endangered species Act of 1973 and subsequent Bureau of Land Management species conservation initiatives. Surveys provide baselines needed for the process of developing a list of sensitive plant species which occur on BLM lands in Montana and for addressing their conservation in the management planning process. This study also contributes to the environmental assessment process of reviewing scattered tracts that may be considered for disposal.

The Great Falls Resource Area Office of the Bureau of Land Management is reviewing scattered tracts that may be appropriate for land exchange or disposal (Table 1. BLM scattered tracts in the Great Falls Resource Area). The 26 scattered tracts collectively represent the most extensive low-elevation holdings under BLM surface management in the area.

Little indian breadroot (Psoralea hypogaea) is the only sensitive plant species on the proposed BLM plant list for the Great Falls Resource Area (USDI Bureau of Land Management 1993), and occupies low-elevation habitat. The scattered BLM tracts have among the greatest potential for little indian breadroot habitat in the resource area, so survey for little indian breadroot was initiated as part of the tract review process.

This final report describes the systematic survey procedures and results, with detailed site and statewide information about little indian breadroot and Craw's sedge. 
III. STUDY METHODS

Available background information was compiled on the 26 BLM scattered tracts and on little indian breadroot to develop the most effective survey methods.

BLM surface management maps (1:100,000 scale-series) were provided by the Great Falls Resource Are office showing tract location, and used for navigation and setting evaluation priorities. Maps included: Great Falls North (1976), Great Falls South (1976), and the Dearborn River (1975). Priorities were based on elevation in the range of plains habitat and on presence of sandy soils as needed by little indian breadroot; soils mapping was available only for cascade county (USDA Soil Conservation Service 1982). Among the 26 scattered tracts, 13 were targeted for inventory (Table 1). The U.S. Geological topographic maps for each tract were assembled and used in fieldwork.

Information compiled on little indian breadroot indicated that the plant is most conspicuous in flower, but that it may also be identified in fruit. The species flowers in late spring (late May - early June) and the infloresence persists for some weeks before breaking off. In keeping with its phenology, fieldwork was conducted on 22-24 May and 5-6 July.

Prior to fieldwork, the Biological Conservation Database maintained by the Montana Natural Heritage Program was queried for records of little indian breadroot across the state, and state species of special concern in the study area. Little indian breadroot was represented by two Montana records: 1) An 1886 collection labelled only "Great Falls", and 2) A 1984 collection made in a mining area in Rosebud county It was not possible to relocate the cascade Co. collection site with its vague locality description to develop a local search image. Across its range, this species occupies droughty habitat on sandplains, on bluffs below sandstone erosion facies, and on droughty stream terraces (Great Plains Flora Association 1986), and all three settings were considered in the course of fieldwork.

A collection of little indian breadroot had also been made along Missouri River bluffs (Lesica pers. commun.), warranting a double-check with herbarium records at the University of Montana. Lesica collected little indian breadroot in 1990 in Choteau County near the Missouri River on or near BLM lands in the Havre Resource Area of the Lewiston District.

The Biological Conservation Database also produced records for twelve other species in the Great Falls Resource Area, five of which are in the Cascade or Lewis and Clark county area at low 
habitat, and most of them represent historic collection records with insufficient locality information to evaluate the likelihood of their occurring on BLM tracts (Appendix 1. Printouts of previous records for plant species of special concern from low elevations - Great Falls Resource Area).

Not all of the 13 BLM tracts targeted for field survey were evaluated on the ground. Some targeted tracts were eliminated from further consideration based on evaluation of nearby sites of the same habitat or by inspecting the tract and its adjoining habitat from a distance. Three tracts were traversed and evaluated on the ground. The level of inventory work is indicated by site (Table 1).

At each site, the overall setting and prevailing vegetation were characterized. Management considerations were noted regarding noxious weeds and access. The study was strictly aimed at surveying BLM lands, but privately-owned lands had to be considered in obtaining access permission to the BLM tracts. One private parcel was included in the survey serendipitously because it was contiguous with a highly significant BIM tract and appeared to have little indian breadroot potential habitat.

Sensitive plant field data was recorded on sensitive plant survey forms, later transcribed onto the element occurrence record form for standardized data entry by the Montana Natural Heritage Program. Voucher specimens were collected and are deposited at the University of Montana Herbarium (MONTU). After the fieldwork, additional information was compiled on each of the target species located in the course of fieldwork, to prepare a species status summary. 
Table. 1. BLM scattered tracts in the Great Falls Resource Area

Tracts for Rare clant (Fsoralea) irventory: Great FaIIs Resource Areas:Cascade, ienis \& Clark, Teton Colnties

Lease

Reference

\# Tract Description

38 R.Go:deiro isas $\triangleq$ T.20NR.1Wsec. 26 ,

1149 Goodman Ui T.18R.3E sec. 3

53 A.ritson İase, T.15NR.2E sec. $2 \dot{4}$

57 A A.MCDanieis iease, T.15HR. $2 \%$ sez. IC

11189 Tunnel $\# 3$ JL T.16IR. 3W sec. 26, LC:S7GE

11188 Ferry Cros $=$ ng UL T.16NR. 3W sec. 24, L5\&T

11187 Mid-Caron LiL T.16NR2W sec.20, i io

22 R. H.Jones liase T.18NR.1E sec.28, IJiNi

37 W. Tonne iEsse:
1155 Bij Dry Ui. SEC. E, Sriti

1128 Coraora Ui $.23 \mathrm{NR} .1 \mathrm{~W}$ sec.19, SeNh

1123 Fairfield Ui T.21NR. 3W sec. 15, SeSe

1121 Floneree 3utze UL T.20nR. 3W sec 2, lot?

20 G.Chiesler iease T.21N.R. $5 E$ seC 2, EiT, Sritie

1190 Mornoy lease T.2NR.5E SeC. 11, NWS

41 R.Gruel lezse, T.22N.R.6 $3 \mathrm{sec} .13,19,3$

65 Neumeyer lease. T.22NR. 5 E sec.25, NeSw

$10 \mathrm{C}$ Bloom lease T.20NR3W sec. $28, \mathrm{NH}$

58 Broken O lease T.20NR. $3 \mathrm{~W}$ sec. 18, WWW

1188 Birdtail UL T.18N.R.3W sec.30, WWWN

57 R. Levire Iease T.17NR. $3 \mathrm{~W}$ sec. 20 , E

85 F.Thompson 1 ase T.16NR. $4 \mathrm{~W}$ sec.32, siiti

32 Steinback lease T.16NR.6W sec.4, iNile

80 Soap Cr. Catzle T.17NR.6W sec.2, :ie E

11050 Dry Creek ijL T.19NR.5W sec.18, ijwlie

8g R. WEarly T.20:i.R.5W sec.32, Wiin

ilap

Inventory

120 iC GF South -

$10 \therefore \approx G \bar{F}$ south

150 AC GE South.

IT: AC GE South

ET AC GE South

54 AC GF South

15 ic GE South

\pm 0 ic GF South

40 AC GE Horth

10 ic GE North

40 ic GF North

10 AC GE lorth

10 h. GE North

$120 \therefore C$ GF North

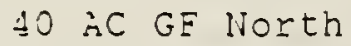

$251 \therefore C$ GF North

40 AC GE North

160 AC Dearborn -

95 AC Dearborn

12 AC Dearborn

320 AC Dearborn

10 iC Dearborn

40 AC Dearborn

40 Aे Dearborn

\pm 0 Ac Dearborn

80 is Dearborn

- Considered for inventory, but ruled out in further review

* Evaluated in detail on foot 
Table 2. Special status plants of the Great Falls Resource Area

\begin{tabular}{|l|l|l||}
\hline Scientific Name* & $\begin{array}{l}\text { BLM proposed } \\
\text { status }\end{array}$ & $\begin{array}{l}\text { Global Rank } \\
\text { /State Rank }\end{array}$ \\
\hline Bacopa rotundifolia & Watch & G5 S1 \\
\hline Carex sychnocephala & - & G4 S1 \\
\hline Centunculus minimus & - & G5 S1 \\
\hline Cyperus acuminatus & Watch & G5 S1 \\
\hline Elodea longivaginata & Watch & G4G5 S1 \\
\hline Halimolobos virgata & Watch & G2G3 S1 \\
\hline Mirabilis hirsuta & Watch & G5 S1 \\
\hline Najas guadalupensis & - & G5 S1 \\
\hline Orchis rotundifolia & Watch & G5 S2S3 \\
\hline Psilocarphus brevissimus & - & G5 S1 \\
\hline Psoralea hypogaea & Sensitive & G3G4 S1 \\
\hline Ranunculus cardiophyllus & Watch & G4 S1 \\
\hline Triglochin concinnum var. debile & Watch & G5T4 S1 \\
\hline
\end{tabular}

*Those species which are bold-faced are ones which have been documented in cascade or Lewis and clark counties from low elevations.

'Taken from USDI Bureau of Land Management (1993), with addition of four species having no BLM status but documented from the Great Falls area before the turn of the century, and tracked as species of special concern by the Montana Natural Heritage Program.

2 Global rank (GRANK) refers to degree of global imperilment throughout a species' range; state rank (SRANK) refers to degree of imperilment in the Montana portion of a species' range, in the following categories:

1 critically imperiled

2 imperiled

3 vulnerable

4 potentially secure

5 secure 
IV. RESULTS

Little indian breadroot (Psoralea hypogaea) does not occur on BLM scattered tracts in the Great Falls Resource Area of the Lewiston District, though it was found to occupy habitat directly adjoining BLM Tract \#22. It had only been seen once before in Cascade county, 107 years ago, and the new record represents the fifth time it has been found in Montana.

The low elevation scattered tracts were considered to represent the greatest potential for finding this species in the Great Falls Resource Area, but its absence from these tracts does not rule out a small possibility of finding suitable habitat in other BLM-administered lands in the Great Falls Resource Area.

The information gathered as a result of this study expands the compendium of knowledge about this species in the state, which may be applicable in the Miles City District or for other BLMadministered lands in the Great Falls Resource Area. Consultation with other botanists in the state substantially expanded known information about this species, most notably in the collection of little indian breadroot on or near BLMadministered lands in the Havre District of the Lewistown District (Lesica pers. commun).

One other state species of special concern was discovered within BLM Tract \#22 in wetland habitat: Craw's sedge (Carex crawei). occurring with it as a spikerush which has been verified as flatstemmed spikerush (Eleocharis compressa), which would represent a new addition to the state flora, but which requires further taxonomic research.

Information about little indian breadroot and Craw's sedge is presented in Appendix 3 and incorporated into species status summaries on the following pages.

While various conservation opportunities may be associated with the BLM tracts that were evaluated, only BLM Tract \#22 was found to harbor state species of special concern that are recommended for further BLM consideration. In addition to harboring a rare species, this tract is part of an intact landscape contiguous with little indian breadroot habitat, and it features an excellent prairie-wetland mosaic that may be state significance in its vegetation. The apparent biodiversity features of this tract and surrounding lands were compiled and described on a natural areas report form (Appendix 4). 
Psoralea hypogaea status summary

\section{NOMENCLATURE}

SCIENTIFIC NAME: Psoralea hypogaea Nutt. ex T. \& G.

COMMON NAME: Little indian breadroot, or subterranean breadroot

FAMILY: Fabaceae (Bean Family)

GENUS: Psoralea (scurf-pea)

SPECIES: P. hypogaea, from the Greek word hypo, meaning "beneath", and the Greek word gaea, referring to the earth. Like the more common $\underline{p}$. esculenta (indian breadroot), the elongate taproot of $\underline{P}$. hypogaea is thickened into a swollen carbohydraterich storage organ below ground that is edible.

\section{FEDERAL STATUS}

U.S. FISH AND WILDLIFE SERVICE: None at present. It has a global rank of $\mathrm{G} 3 \mathrm{G} 4$, indicating that it may be vulnerable rangewide. It has been informally discussed as a species which may warrant addition to the Federal Register Notice of Review for consideration as threatened or endangered (Shelly pers. commun.). It has also been noted that it appears to be rare throughout its range (Great Plains Flora Association 1986).

BUREAU OF LAND MANAGEMENT: Sensitive in the Great Falls Resource Area, Watch in the Powder River Resource Area (USDI Bureau of Land Management 1993). As a result of this work, it is recommended that the sensitive status be changed to watch in the Great Falls Resource Area, but kept as sensitive in the Lewistown District based on a recent Havre Resource Area record.

U.S. FOREST SERVICE: None; it does not appear to reach the elevations of national forests in Montana.

STATE STATUS: Its state Rank is "S1", indicating that it is critically imperiled. This is based on a total of four collections to date, one of which may represent an extirpated population, and two of which are in mining project areas.

It was placed in the "threatened" category by Lesica and Shelly (1991), but neither this treatment or the state rarity rank confer a protection status. 
GENERAL NONTECHNICAL DESCRIPTION: Little indian breadroot is an herbaceous perennial with a compact spike-like infloresence of purple flowers connected to the taproot with little or no vestige of a flowering stalk, overtopped and partly hidden by silvery leaves made up of five leaflets joined at the base like a palm or fan (Figure 1. Psoralea hypogaea, close-up). The leaves sometimes lie appressed to the substrate, so that the entire plant seems to hug the ground. It produces relatively inconspicuous one-seeded pods.

TECHNICAL DESCRIPTION: Perennial acaulescent herbs or rarely with stems $1-2 \mathrm{~cm}$ long and internodes very short; taproot apically thickened into a globose or fusiform storage organ 3-8 $\mathrm{cm}$ below surface; caudex a knobby, usually conical structure at apex of storage organ, producing 1(2-4) vertical slender stipulebearing branches which enlarge at surface to produce crown of the season. Leaves palmately 3-5(7)-foliate, entirely covered with densely appressed white pubescence or upper surface of leaflets becoming glabrate; leaflets linear-elliptic, linear-lanceolate to rarely narrowly obovate, (1.5) $2.5-5 \mathrm{~cm}$ long, 4-9 $\mathrm{mm}$ wide; petioles (2) 4-9(12) cm long; stipules lanceolate to ovate, 0.5-2 $\mathrm{cm}$ long, scarious. Peduncles very short to rarely as long as leaves in fruit; spike dense; bracts ovate-acuminate or lanceolate, scarious, 5-8 mm long, glabrous above, strigose below, ciliate. Calyx tube 4-5 mm long, hirsute, 4 upper teeth lanceolate, 5-7 mm long, lower tooth 9-11 mm long and 3-4 mm wide, 3-veined; corolla blue or violet, fading yellowish; banner ovate-oblong, blade 10-13 mm long, claw 2-3 mm long; wing narrowly oblong, 9-10 mm long, claw 2-3 mm long; free portion of keel 3-4 mm long. Pod ovoid, 5-6 mm long, hirsute, tapering into a beak 8-13 mm long, pericarp thin in lower 1/3, leathery above, irregularly circumscissile; seed 4-5 mm long, 2.5-3 mm wide, $2 \mathrm{~mm}$ in diam, faces with conspicuous irregular rounded ridges, olivaceous or pinkish-gray (Great Plains Flora Association 1986).

LOCAL FIELD CHARACTERS: Little indian breadroot superficially resembles other palmately-leaved legumes, which are known to or are expected to occupy similar habitats in Montana. It most closely resembles common indian breadroot, but unlike this species, it has an infloresence much shorter than the leaves, without a central flowering stalk or a highly reduced flowering stalk. This gives it the appearance of hugging the ground (Figure 1). Compared to common indian breadroot it also has appressed pubesence instead of hirsute leaves, its flowers are smaller at 10-13 mm as compared to ca. $15 \mathrm{~mm}$., darker in color, the calyx tube is shorter at 3-4 mm as compared to ca. $5 \mathrm{~mm}$, and the calyx tube lobes are larger on the bottom as compared to equal in size.

If the infloresence of little indian breadroot is overlooked, it 


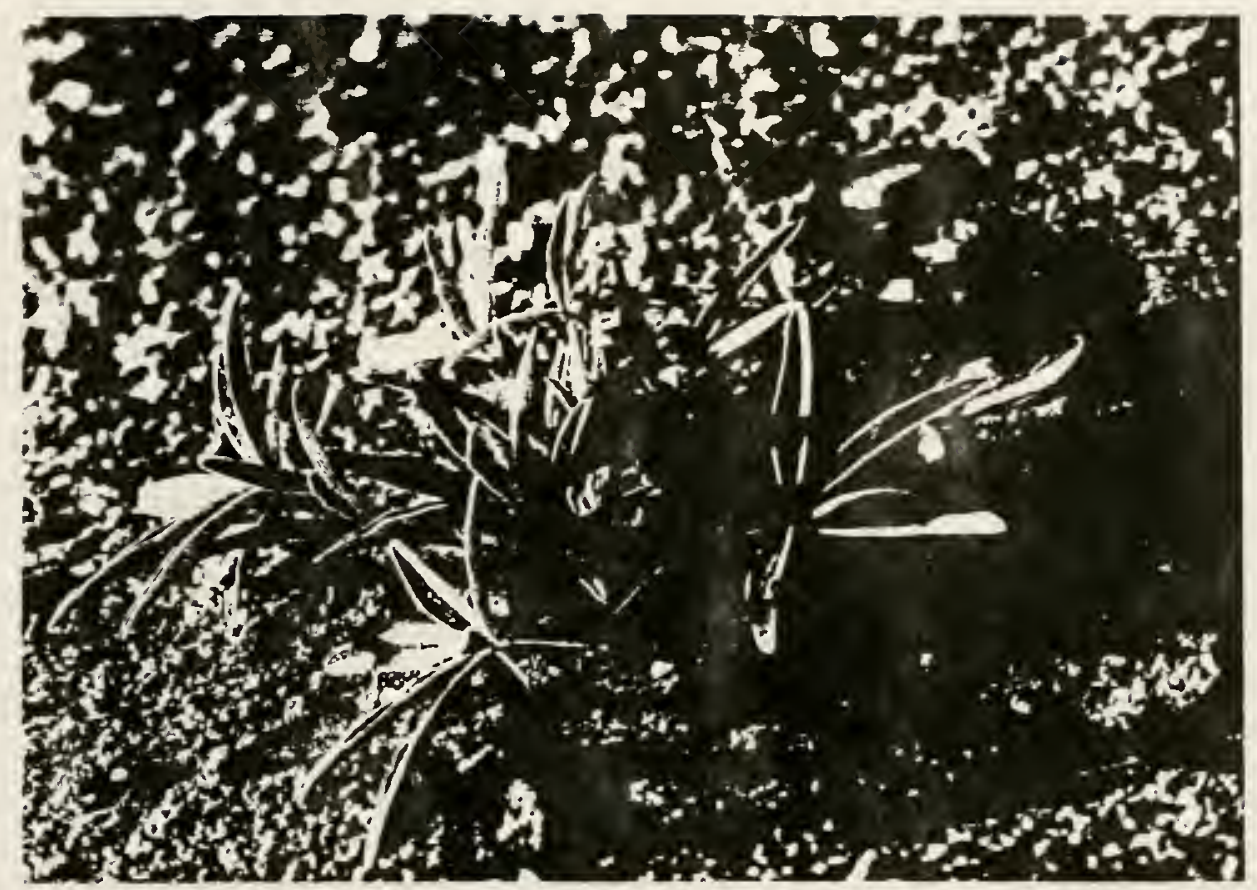

Figure 1. Psoralea hypogaea, close-up

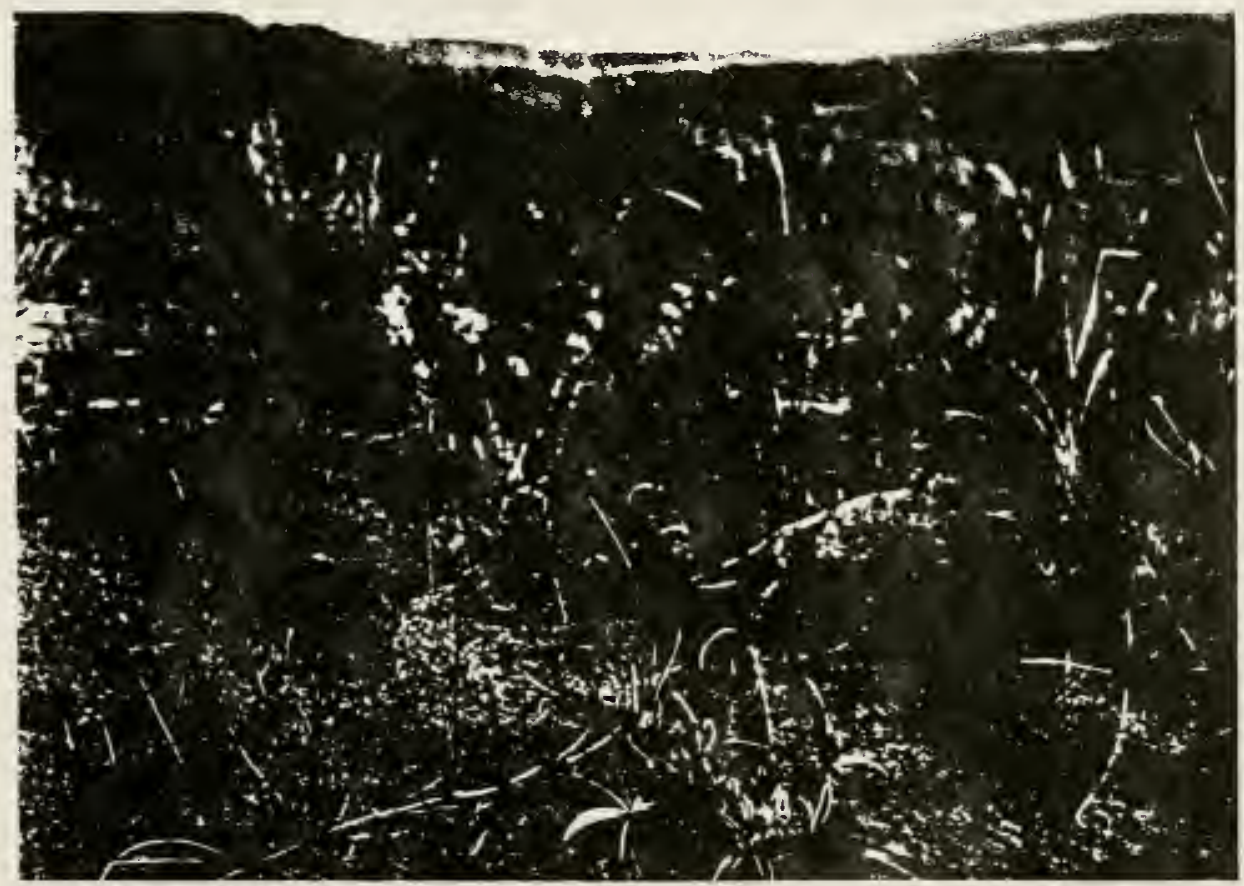

Figure 2. Psoralea hypogaea, habitat 
If the infloresence of little indian breadroot is overlooked, it might be mistaken for an immature lupine, like the lupinus argenteus that is locally common around the newly documented little indian breadroot site.

Other leguminous species bearing remote semblance to little indian breadroot have only three-leaflet compound leaves, besides having other differences. These species include yellow goldenpea (Thermopsis rhombifolia), which is also distinguished in having a yellow flower, silverleaf (Psoralea argophylla), which is also distinguished in having an open racemose infloresence, and small lupine (Lupinus pusillus), which is an annual with a distinct flowering stem. The latter was not found at the cascade co. site but might be expected to overlap with little indian breadroot elsewhere in its habitat.

\section{GEOGRAPHICAL DISTRIBUTION}

RANGE: Little indian breadroot is restricted to the Great Plains, extending from Montana to New Mexico, and eastward as far as western South Dakota, Nebraska, Kansas and Oklahoma (Great Plains Flora Association 1976). Montana represents the northern end of its distribution.

CURRENT SITES: Four recent, relocatable sites represent the current distribution of little indian breadroot in Montana.

The record for a Rosebud co. collection actually represents two locations, both from mining areas near colstrip (Scow pers. commun.). The little indian breadroot grows on both native habitat and reclamation habitat. The locations are described as: Peabody's Big Sky Mine, and Western Energy's Rosebud Mine (Scow pers. commun.), but the specimen label upon which the single Rosebud Co. record is based does not provide this level of location detail.

One is from Choteau county along the Missouri River breaks. The most recent one is from Cascade county, also along the Missouri River, in a small area with sand blowouts. These records are printed out in Appendix 2 .

HISTORICAL SITES: The first collection in cascade county was made in 1882, and the label information said only "Great Falls". If it was collected at the actual townsite, then the population is likely to be extirpated. Sandy habitats in the immediate vicinity of town include now-inundated Missouri River terraces, the radio tower buttes north and northwest of town, and the bluffs of sand coulee southeast of town. 
UNVERIFIED/UNDOCUMENTED REPORTS: OnIY one record has been entered for little indian breadroot from Rosebud county, based strictly on the specimen label information. It is necessary to get copies of the environmental assessment reports to enter existing documentation into the Biological Conservation Database.

\section{HABITAT}

ASSOCIATED VEGETATION: The vegetation associated with little indian breadroot represents early successional sand prairie. In Rosebud County sites, this is present on eroding sandstone bluffs as well as parts of the sandy reclaimed mine sites. In the newly-documented Cascade county site, this is present in active blowouts along a sandy ridge (Figure 2. Psoralea hypogaea, habitat). There, the habitat is very sparsely vegetated, with the most common grass usually being prairie sandreed (Calomovilfa longifolia). The vegetation has a high component of legumes besides little indian breadroot, which are nitrogen fixers. These include: silver lupine (Lupinus argenteus), goldenpea (Thermopsis rhomboideus), and silverleaf psoralea argophylla). other early-successional sand-loving species at the Cascade Co. site include: sand dropseed (sporobolus cryptandrus), indian ricegrass (oryzopsis hymenoides), and wild begonia (Rumex venosus), as well as generalists like needle-and-thread (stipa comata), western wheatgrass (Agropyron smithii), broom snakeweed (Gutierrezia sarothrae), and Russian thistle (Salsola kali).

Most short-lived weedy blowout species that are present elsewhere at blowouts of the cascade co. site were not present in the particular three blowouts that harbor little indian breadroot; those not present include: narrow-leaved goosefoot (Chenopodium leptophyllum) and Douglas' knotweed (Polygonum douglasii).

Associated vegetation information for other sites of little indian breadroot is meager. The Rosebud county collection notes a sandy ponderosa pine grassland or open woodland. The Choteau county record notes association with blue grama (Bouteloua gracilis) and ground plum (Astragalus missouriensis).

SOIL RELATIONSHIPS: Soils are psamments, with almost no horizon development or organic component. They are in the "sands" soil texture category and sands range site, representing the most droughty soils in the state. They have rapid water percolation and almost no water-retaining capacity.

At the newly-documented cascade co. site, these soils are developed from sandy periglacial alluvial deposits, perhaps representing a sand delta. This sandy feature is highly localized, and encompassed within the "alluvium" surface geology category as mapped by Ross et al. (1955). Soils at the Cascade Co. Site are mapped as Lihen loamy sand, 8-20\% slopes (Unit 128; 
USDA Soil conservation Service 1982). It includes soils developed from both alluvial and aeolian sand deposits. Incidentally, in cascade county, this unit is restricted to an estimated 2,356 acres, or $0.2 \%$ of the county area (USDA Soil Conservation Service 1982). Most of it is located in the immediate vicinity of the little indian breadroot site.

The soils of little indian breadroot sites in other counties represent sandy colluvium eroded from bedrock. Soil series types are unknown.

REGIONAL CLIMATE: Soils of the Cascade Co. site developed under a continental climate with mean annual precipitation of 14-16 inches, and a growing season of 105-135 days (USDA Soil conservation service 1982). The mean annual air temperature is 43-45 degrees $F$. These are the climate patterns expected at other little indian breadroot sites.

\section{POPULATION BIOLOGY}

PHENOLOGY: Flowering takes place as days lengthen and temperatures increase late in the spring. Fruits mature in June, typically the month of peak rainfall. The phenological window during which plants are most conspicuous corresponds with flowering, though identification can be made with certainty any time while the infloresence persists through at least early July.

POPULATION SIZE AND CONDITION: The Choteau collection site is the only place where little indian breadroot is known and noted as common. It is possible that population size information exists for the two Rosebud county collections made by Western Technology, Inc. researchers at mine sites, and this information will be sought from unpublished reports. It would be interesting to know the aerial extent, density, and total numbers of plants on intact habitat vs. reclamation habitat.

The Cascade county population was made up of at total of seven plants in three separate blowouts; five plants were at one blowout. The three occupied blowouts span a distance of $1 / 4$ mile. Included among the individuals were plants of varying sizes, possibly indicating a range in ages.

\section{REPRODUCTIVE BIOLOGY}

TYPE OF REPRODUCTION: Reproduction is sexual; it is not known to what degree selfing occurs. Plants are dieocious and flowers are perfect. Examination of specimens indicated that at least some of the flowers are open, ruling out the cleistogamous condition. 
POLLINATION BIOLOGY: Pollinators were not observed. Bees are pollen vectors for many legumes. Population numbers of little indian breadroot are so low at the cascade county site that the pollinator must either be a generalist, or else there is a shortage of pollinators.

SEED DISPERSAL AND BIOLOGY: The single-seeded fruits crack and rupture with drying rather than having a line of dehisence. It is likely that little indian breadroot seeds disperse like the seeds of common indian breadroot, scattering when the dried infloresence breaks off and is blown by the wind. 
Carex crawei status summary

NOMENCLATURE

SCIENTIFIC NAME: Carex crawei Dewey

COMMON NAME: Craw's sedge

FAMILY: Cyperaceae (Sedge Family)

GENUS: Carex The sedge genus is the largest genus in the world, and the largest genus in the flora of Montana. The genus is broken down into well-recognized sections. Craw's sedge is in the section Granulares.

SPECIES: $\underline{c}$. crawei. The genus is named after a nineteenth century collector.

\section{FEDERAL STATUS}

\section{U.S. FISH AND WILDLIFE SERVICE: None.}

BUREAU OF LAND MANAGEMENT: Craw's sedge was not previously considered by the Bureau of Land Management as a prospective species of special concern because it was not previously known from the vicinity of BLM-administered lands until 1992 when it was collected in the Miles City District. This study is the second documentation of the species on BLM-administered lands and, considering its rarity in Montana, provides basis for recommending that it be considered for sensitive species designation.

U.S. FOREST SERVICE: NONE.

STATE STATUS: Craw's sedge has a state rank of $\mathrm{S} 1$, based on a current total of six records. It was placed in the "sensitive" category by Lesica and Shelly (1991), but neither this treatment or the state rarity rank confer a protection status.

\section{DESCRIPTION}

GENERAL NONTECHNICAL DESCRIPTION: Craw's sedge is an herbaceous perennial 1-3 dm tall that appears single-stemmed or in small clusters, connected by underground rhizomes (Figure 3. Photograph of Carex crawei, close-up). The spikes are short, compact and upright. They are scattered along over half of the length of the stem, and overtop the short stem "leaves". 
It is necessary to examine technical characteristics of flower parts and the fruiting structure ("perigynia") to make positive identification.

TECHNICAL DESCRIPTION: Carex crawei keys out to "Group IV" in Hitchcock and cronquist (1973) and Hitchcock et al. (1966); and in "Group V" by the same characters in Dorn (1984), based on having multiple spikes, three stigmas, and a glabrous perigynia.

In this large synthetic group, it is distinguished in having lowermost bracts with sheaths and bracts shorter than the infloresence, with a beakless or very short-beaked perigynia.

It keys out the Granulares section in Hermann (1970) based on the above characteristics, in addition to its deciduous style, scales not leaf-like, pistillate spikes short and erect, and the perigynia rounded at the base, suborbicular in cross-section, loosely enveloping the achene.

Its technical characteristics include the following: stems arising singly or few together from well-developed rhizomes, 1-3 dm tall, phyllopodic or only slightly aphyllopodic; flat leaves mostly $1.5-3 \mathrm{~mm}$ wide. Spikes cylindric, $1-2.5 \mathrm{~cm}$ long, compactly 15- to 50-flowered, generally remote along stem, all erect and short-pedunculate, lowermost often nearly basal, subtended by leaves with well-developed sheath and blade, the terminal spike staminate, laterals ones $2-4$ (6), pistillate or the upper androgynous, the peduncle often scarcely surpassing the subtending sheath, or the lowest ones on long peduncles. Bract sheath mostly 5-15 mm long, the blade elongate but surpassed by the terminal spike, upper bracts with reduced blade but still well-developed sheath. Perigynia elliptic or ovate-elliptic, greenish-stramineous to tan or light brownish, often finely reddish-brown-speckled, $2.3-3.8 \mathrm{~mm}$ long, including the very short or obsolete beak which is truncate or slightly bidentate, 1-5 to 25-nerved, sometimes flattened on adaxial side, otherwise subinflated, only the angles of the achene in contact with the perigynia wall, otherwise distal part of perigynia empty, stigmas 3 , achene trigonous and $1.3-1.7 \mathrm{~mm}$ long, style deciduous (from Hitchcock et al 1969).

LOCAL FIELD CHARACTERS: Sedges make up the largest genus in the Montana flora, and definitive identification of this species, like most sedge species, requires examination of technical characteristics with a hand lens.

Distinguishing features to look for in the field include the erect spikes scattered over half the length of the stem and looking superficially like a short string of beebees, and the lack of clumping among stems (Figure 3. Carex crawei, close-up). The habitat is also diagnostic, typically having marl at the surface. 


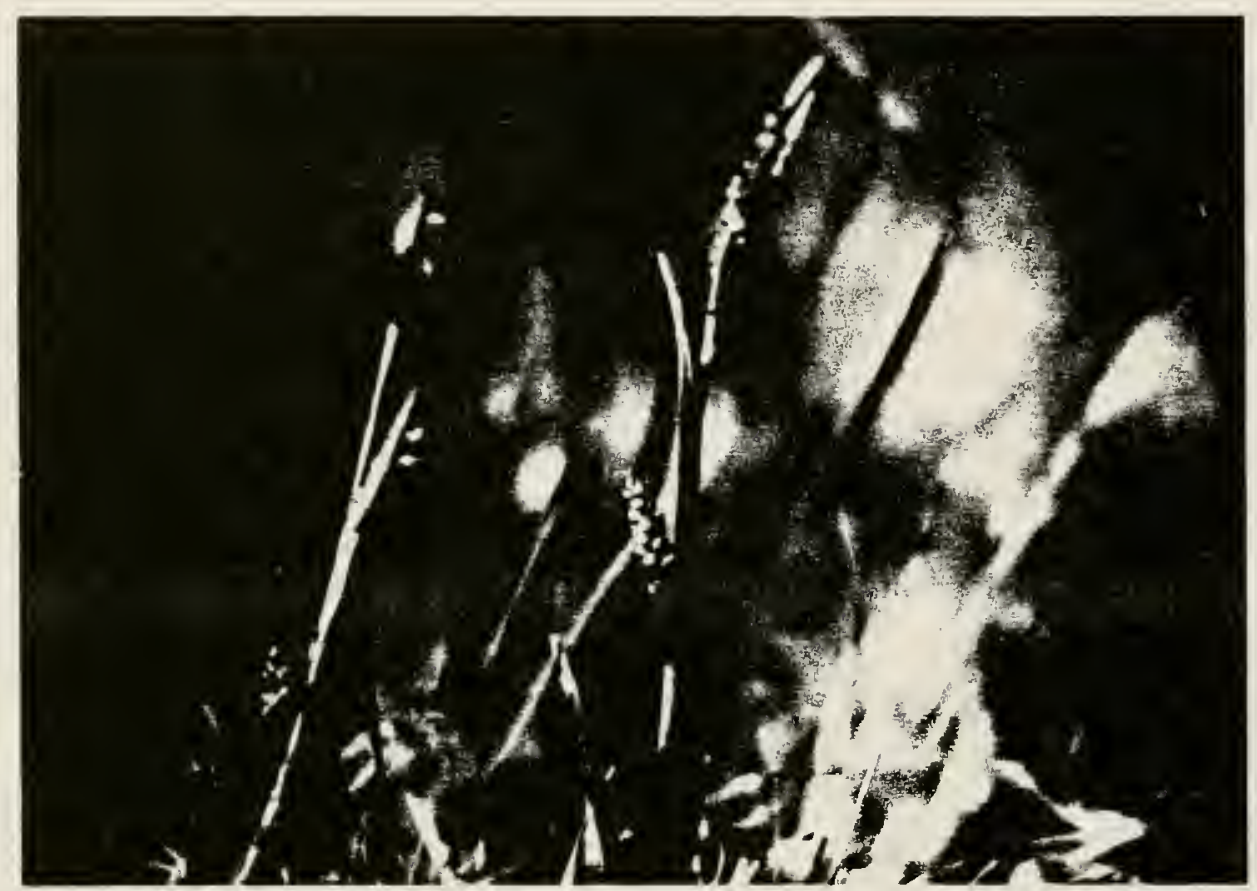

Figure 3. Carex crawei, close-up 


\section{GEOGRAPHICAL DISTRIBUTION}

RANGE: Craw's sedge is a widely-distributed boreal species ranging from British columbia to quebec, with southern extensions as far south as Utah and Alabama. It's occurrences in Montana are peripheral range extensions southward mainly along the Rocky Mountain chain.

CURRENT SITES: In Montana, Craw's sedge is known from a total of six recently documented sites. Until recently, it was just known from the foothills of the Front Range in Pondera and Teton counties. In 1992 it was collected in Prairie county from BLMadministered land, representing a major state range extension. The new Cascade county site represents a minor state range extension separated from the Rocky Mountain chain. All records are printed out in Appendix 3.

HISTORICAL SITES: NONE.

UNVERIFIED/UNDOCUMENTED REPORTS: This species is also reported in southwestern Montana (possibly Beaverhead county according to Hitchcock and Cronquist 1973), but we have been unable to locate the corroborating voucher specimen information to date.

\section{HABITAT}

ASSOCIATED VEGETATION: The habitat of Craw's sedge in Montana has been characterized as "gravelly, calcareous shores of ponds and streams in the valley and foothill zones, 1310-1490 $\mathrm{m} \mathrm{(4,300-}$ $4,900 \mathrm{ft}$ ); (Lesica and Shelly 1991). Its habitat in the Pacific Northwest has been characterized as "wet places at lower elevation, often with limestone or in marl-bogs" (Hitchcock and Cronquist 1973). Both descriptions represent localized settings of alkaline groundwater discharge which often have calcium carbonate precipitating out.

The associated vegetation of Front Range populations typically includes sedges ( Carex lanuginosa, $\underline{c}$. area, $\underline{c}$. oederia, $\underline{c}$. lasiocarpa)

and rushes (Juncus balticus, I. longistylis).

The associated vegetation of the cascade county population is in a small marl bog among a complex of sandhill swales. Local dominants are calamagrostis inexpansa and Juncus balticus. Associated species include carex aurea, c. parryana, Eleocharis compressa and Muhlenbergia richardsonis.

Associated species information at the Prairie county site is incomplete but seems to be similar despite the atypical woody draw setting. 
SOII RELATIONSHIPS: Craw's sedge is found on saturated soils high in calcium carbonates. In the cascade county site, the marl meadow overlies a clay strata that outcrops nearby above Bird creek, and it corresponds with a spring discharge or upwelling. The marl meadow had standing water in mid July of 1993, an unusually wet year, in an unpatterned complex of slight dips and rises, and Craw's sedge was locally common on the rises in this habitat.

REGIONAL CLIMATE: Soils of the Cascade Co. site developed under a continental climate with mean annual precipitation of 14-16 inches, and a growing season of 105-135 days (USDA Soil Conservation service 1982). The mean annual air temperature is 43-45 degrees $F$.

\section{POPULATION BIOLOGY}

PHENOLOGY: Craw's sedge has been collected in Montana from June 12 - July 19. Well-developed perigynia are needed for positive identification, and it is noted that the June 12 material from Prairie county was not fully mature. The perigynia persist after maturing into August, so that identification can be made over a long segment of the growing season.

POPULATION SIZE AND CONDITION: Craw's sedge is the most abundant plant species across the northern half of the marl wetland basin where it is found. Either the basin is differentiated by environmental factors, or there is a successional change in the south half of the basin favoring widespread wetland species that are more tolerant of fluctuating conditions.

Elsewhere, it is restricted to ecotonal zones where it may be uncommon or have numbers in the thousands depending on the site.

\section{REPRODUCTIVE BIOLOGY}

TYPE OF REPRODUCTION: Craw's sedge reproduces sexually and asexually, by its "flowers" and by subterranean rhizomes which expand vegetatively.

POLLINATION BIOLOGY: Flowers of the genus are monoecious and rudimentary, adapted for wind pollination. In this species, the uppermost spike is staminate, and the rest of the spikes are pistillate, or made up of pistillate flowers overtopped by staminate flowers.

SEED DISPERSAL AND BIOLOGY: UnknOWn. 
Eleocharis compressa status summary

\section{NOMENCLATURE}

SCIENTIFIC NAME: Eleocharis compressa Sulliv.

COMMON NAME: Flat-stemmed spikerush

FAMILY: Cyperaceae

GENUS: Eleocharis (spikerush)

SPECIES: $\underline{E}$. compressa, referring to the compressed, or flattened stem.

Species' taxonomy with reference to this specimen is in question. The following text describes the nature of the questions at hand, the methods for resolving them, and the interim recommendations for treatment.

The Cascade County specimen (Heidel \#1106) has been verified as Eleocharis compressa Sulliv. sensu lato ("in the broadest sense") by an expert in the Eleocharis genus, Dr. Paul M. Catling of Agriculture Canada Research Branch in ottawa, ontario. Distinctive features include the "brown, reticulate achenes, rather thick rhizomes and the scarious-tipped scales which are distinctly bifid" (Catling pers. commun.). This represents the first time that material collected in Montana has been determined as Eleocharis compressa.

The flattened stem feature is often used to distinguish between Eleocharis compressa and $\underline{E}$. tenuis in keys treating both species (Fasset 1957, Gleason and Cronquist 1991). The latter species has been documented from fen habitats of Montana on many occasions and is treated as $\underline{E}$. $\underline{t}$. var. borealis throughout the Pacific Northwest (Hitchcock et al 1984). It is noted that $\underline{E}$. compressa passes into $\underline{E}$. tenuis var. borealis (Gleason and Cronquist 1991); in the east according to Fassett (1957). This geographic pattern noted in Fasset (1957) differs from the observation that the "flattened stem" characteristic of $\underline{E}$. compressa is pronounced in plants at the eastern end of species' North American distribution, but plants like the Cascade Co specimen to the west are less pronounced in this feature (Catling pers. commun.).

The Cascade county specimen was initially judged to be different from $\underline{E}$. tenuis when it was first examined because the achenes have a large apical cap that is not depressed, the achenes are a bright golden color, and the rhizomes are densely clustered.

These questions bring into play not only the identification of the Cascade county specimen but the treatment of Eleocharis 
tenuis throughout Montana. It is recommended that another collection be made at the cascade county site, and E. tenuis specimens from University of Montana and Montana state University be sent to Dr. Catling or other Flora of North America experts in the Eleocharis genus.

For the present, Eleocharis compressa will be assigned a state rank of "SU", for status unknown. It will not be tracked unless there is confirmation that it differs taxonomically from existing specimens of $\underline{E}$. tenuis var. borealis in the state.

Information on its technical descriptions, distribution, habitat and biology will be held pending taxonomic resolution.

\section{RECOMMENDATIONS AND CONCLUSIONS}

There is slim probability that little indian breadroot occurs on BLM lands in the Great Falls Resource Area. However, it has been collected on or adjacent to BLM-administered lands in the Havre Resource Area, which represents the only place in the state where it is known to be common. Therefore, it is recommended that its status be retained as sensitive on the BLM proposed list of sensitive and watch plant species.

Discovery of Craw's sedge on BLM lands in the Great Falls Resource Area, and accompanying background information, provides basis for recommending that it be added to the BLM list as sensitive. The flat-stemed spikerush (Eleocharis c.f. compressa) may warrant consideration as sensitive pending resolution of taxonomic questions which are detailed in the status summary.

Among the 26 scattered tracts, there is slim probability for finding any additional target species. This survey covered lowelevation sandy and wetland habitats.

It was observed that most of the low and mid elevation wetland habitats harboring state species of concern in Cascade and Lewis and Clark Counties have disappeared or are degraded. This elevates the importance of discovering rare wetland species in intact habitat on one of the BLM tracts surveyed, Tract \#22. Biodiversity significance is ascribed to BLM Tract \#22 and its surroundings as a result of this survey project. Its sensitive stature in the BLM sensitive species conservation program warrants further consideration. 


\section{LITERATURE CITED}

Barr, C. A. 1983. Jewels of the Plains. University of Minnesota Press. Minneapolis. $236 \mathrm{pp}$.

Dorn, R. D. 1984. Vascular Plants of Montana. Mountain West Publishing. Cheyenne, WY. $276 \mathrm{pp}$.

Fassett, N. C. 1957. A manual of aquatic plants. University of Wisconsin Press. Madison. $405 \mathrm{pp}$.

Gleason, H. A. and A. Cronquist. 1991. Manual of vascular plants of northeastern United States and adjacent Canada. New York Botanical Garden, Bronx. $910 \mathrm{pp}$.

Great Plains Flora Association. 1977. Atlas of the flora of the Great Plains. Iowa State University Press, Ames. 600 pp.

Great Plains Flora Association. 1986. Flora of the Great Plains. University press of Kansas, Lawrence. $1392 \mathrm{pp}$.

Heidel, B. L. and J. M. Poole. 1993. Montana plant species of special concern. Montana Natural Heritage Program, Helena. Unpubl.

Hermann, F. J. 1970. Manual of the Carices of the Rocky Mountains. USDA Forest Service Agriculture Handbook No. 374 . $397 \mathrm{pp}$.

Hitchcock, C.L., A. Cronquist, M. Ownbey and J.W. Thompson. 1984, 4th ed. Vascular Plants of the Pacific Northwest, Part 1. University of Washington Press. Seattle, WA.

Lesica, P. and J. S. Shelly. 1991. Sensitive, threatened and endangered vascular plants of Montana. Montana Natural Heritage Program Occasional Publ. No. 1. Helena. 88 pp.

Scoggan, H. J. 1978. The flora of Canada, Part 2. National Museum of Natural Sciences, Publications in Botany, No. $7(2)$.

USDA Forest Service. 1988. Sensitive plant guide. USDA Forest Service, Region 1 (Northern Region). Missoula, MT.

USDA Soil Conservation Service. 1982. Soil survey of Cascade County Area, Montana. Great Falls. 329 pp. and maps.

U.S. Department of Commerce. 1982. Monthly normals of temperature, precipitation, and heating and cooling degree days 1951-1980. National Oceanic and Atmospheric Administration, Climatography of the United States No. $81.23 \mathrm{pp}$.

USDI Bureau of Land Management. 1993. Draft list of sensitive 
Appendix 1. Printouts of previous records for plant species of special concern from low elevations within the Great Falls Resource Area 
Scientific Name: BACOPA ROTUNDIFOLIA

common Name: ROUNDLEAF WATER-HYSSOP

Global rank: $G 5$

State rank: $\mathrm{SI}$
Forest Service status:

Federal status:

Element occurrence code: PDSCR06080.003

Element occurrence type:

Survey site name: GREAT FALLS

EO rank:

EO rank comments:

county: CASCADE

USGS quadrangle: SOUTHEAST GREAT FALLS

SOUTHWEST GREAT FALLS

Township: Range: Section: TRS comments:

$020 \mathrm{~N}$

$004 \mathrm{E}$

32

Precision: $\quad G$

Survey date:

First observation: 1891

Last observation: 1891-09-08

Elevation: 3340 -

Slope/aspect:

Size (acres):

Location:

LOWER SAND COULEE (HISTORICAL RECORD).

Element occurrence data:

IN FRUIT (13 AUGUST 1891, 3 SEPTEMBER 1891)

General site description:

UNKNOWN. (SPECIES OCCURS ON POND AND STREAM EDGES.)

Land owner/manager:

PRIVATELY OWNED LAND (INDIVIDUAL OR CORPORATE)

Comments :

GENERAL LOCATION, RECORDS OBTAINED FROM MRPP CARDS.

Information source: BOTANIST, MONTANA NATURAL HERITAGE PROGRAM, 1515 EAST SIXTH AVENUE, HELENA, MT 59620-1800.

Specimens: WILLIAMS, R. S. (856). 1891. MONT. 
Scientific Name: CENTUNCULUS MINIMUS

Common Name: CHAFFWEED

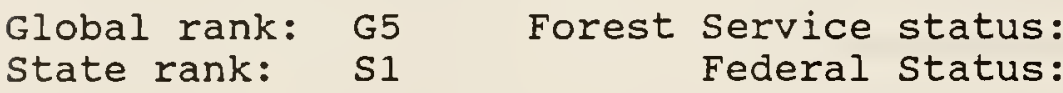

Element occurrence code: PDPRI01020.001

Element occurrence type:

Survey site name: GREAT FALLS

EO rank:

EO rank comments:

county: CASCADE

USGS quadrangle: SOUTHEAST GREAT FALLS

SOUTHWEST GREAT FALLS

Township: Range: Section: TRS comments:

O2ON $004 \mathrm{E} \quad 32$

Precision: $G$

Survey date: 1891-08-11 Elevation: 3340 -

First observation: 1891 Slope/aspect:

Last observation: 1891-09-10 Size (acres):

Location:

GREAT FALLS (HISTORICAL COLLECTION, GENERAL LOCATION INFO.); POSSIBLY OCCURS IN SAND COULEE CREEK DRAINAGE, OR NEAR MISSOURI RIVER.

Element occurrence data:

UNKNOWN.

General site description:

UNKNOWN; SPECIES OCCURS IN DRYING VERNAL PONDS AND SIMILAR HABITATS.

Land owner/manager:

PRIVATELY OWNED LAND (INDIVIDUAL OR CORPORATE)

Comments:

Information source: BOTANIST, MONTANA NATURAL HERITAGE PROGRAM, 1515 EAST SIXTH AVENUE, HELENA, MT 59620-1800.

Specimens: WILLIAMS, R. S. (693). 1891. SPECIMEN \#4080. MONT. 
Scientific Name: CAREX SYCHNOCEPHALA

Common Name: MANY-HEADED SEDGE

Global rank: G4 Forest Service status:

state rank: 51 Federal status:

Element occurrence code: PMCYP03DE0.001

Element occurrence type:

Survey site name: GREAT FALLS

EO rank:

EO rank comments:

county: CASCADE

USGS quadrangle: SOUTHEAST GREAT FALLS

SOUTHWEST GREAT FALLS

Township: Range: Section: TRS comments:

020N $004 \mathrm{E} \quad 32$

Precision: G

Survey date: Elevation: 3340 -

First observation: 1890 Slope/aspect:

Last observation: 1891-09-08 Size (acres):

Location:

GREAT FALLS (HISTORICAL COLLECTION, GENERAL LABEL INFORMATION);

POSSIBLY OCCURS IN SAND COULEE CREEK DRAINAGE, OR NEAR MISSOURI RIVER.

Element occurrence data:

UNKNOWN .

General site description:

UNKNOWN; SPECIES OCCURS IN MOIST MEADOWS, LAKE SHORES, AND THICKETS AT LOW ELEVATIONS.

Land owner/manager:

PRIVATELY OWNED LAND (INDIVIDUAL OR CORPORATE)

Comments:

RECORD OBTAINED FROM MRPP FILE, MONTU.

Information source: BOTANIST, MONTANA NATURAL HERITAGE PROGRAM, 1515 EAST SIXTH AVENUE, HELENA, MT 59620-1800.

Specimens: WILLIAMS, R. S. (S.N.). 1890 AND 1891. MONT. 
Scientific Name: NAJAS GUADALUPENSIS

Common Name: GUADALUPE WATER-NYMPH

Global rank: $G 5$

state rank: $\mathrm{SI}$
Forest Service status:

Federal status:

Element occurrence code: PMNAJ01050.002

Element occurrence type:

Survey site name: SAND COULEE EO rank:

EO rank comments:

County: CASCADE

USGS quadrangle: SOUTHEAST GREAT FALLS

Township: Range: Section: TRS comments:

$020 \mathrm{~N}$

OO4E 25

Precision: $G$

Survey date:

First observation: 1891

Last observation: 1891-08-25

Elevation: 3360 -

Slope/aspect:

Size (acres):

Location:

LOWER SAND COULEE (HISTORICAL COLLECTION, GENERAL LABEL

INFORMATION) .

Element occurrence data:

UNKNOWN .

General site description:

POND.

Land owner/manager:

PRIVATELY OWNED LAND (INDIVIDUAL OR CORPORATE)

Comments:

RECORD OBTAINED FROM MRPP FILE, MONTU.

Information source: BOTANIST, MONTANA NATURAL HERITAGE PROGRAM, 1515 EAST SIXTH AVENUE, HELENA, MT 59620-1800.

Specimens: WILLIAMS, R. S. (858). 1891. SPECIMEN \#15528. MONT. 
Scientific Name: PSILOCARPHUS BREVISSIMUS

Common Name: DWARF WOOLLY-HEADS

Global rank: $\mathrm{G5}$

state rank: SI

Forest Service status:

Federal status:

Element occurrence code: PDAST7R010.001

Element occurrence type:

Survey site name: SAND COULEE

EO rank:

EO rank comments:

County: CASCADE

USGS quadrangle: SOUTHEAST GREAT FALLS

Township: Range: Section: TRS comments:

$020 \mathrm{~N}$ OO4E 25

Precision: $G$

Survey date:

First observation:

Last observation:
1891

$1891-08-13$
Elevation: 3360 -

Slope/aspect:

size (acres):

Location:

LOWER SAND COULEE (HISTORICAL COLLECTION, GENERAL LABEL INFORMATION.)

Element occurrence data:

UNKNOWN .

General site description:

SPECIES OCCURS IN DRYING VERNAL POOLS.

Land owner/manager:

PRIVATELY OWNED LAND (INDIVIDUAL OR CORPORATE)

Comments:

RECORD OBTAINED FROM MRPP FILE, MONTU. LABELED EVAX PROLIFERA;

ANNOTATED BY R. DORN, 1975.

Information source: BOTANIST, MONTANA NATURAL HERITAGE PROGRAM, 1515 EAST SIXTH AVENUE, HELENA, MT 59620-1800.

Specimens: WILLIAMS, R.S. (784). 1891. SPECIMEN \#1085. MONT. 
Appendix 2. Printouts of Psoralea hypogaea in Montana 
Scientific Name: PSORALEA HYPOGAEA

Common Name: LITTLE INDIAN BREADROOT

Global rank: $G 3 G 4$

State rank: $\mathrm{SI}$
Forest Service status:

Federal status:

Element occurrence code: PDFAB5L0C1.001

Element occurrence type:

Survey site name: LEE COULEE

EO rank:

EO rank comments:

County: ROSEBUD

USGS quadrangle: COLSTRIP SW

Township: Range: Section: TRS comments:

001N $041 \mathrm{E} \quad 29$ NW4

Precision: $M$

Survey date: 1984-06-06 Elevation: 3380 -

First observation: 1984

Last observation: 1984-06-06 Size (acres): 0

Location:

CA. 0.75 AIR MILES NORTH OF LEE COULEE, CA. 5 AIR MILES SSW OF COLSTRIP.

Element occurrence data:

UNKNOWN.

General site description:

SANDY PINUS PONDEROSA GRASSLAND.

Land owner/manager:

PRIVATELY OWNED LAND (INDIVIDUAL OR CORPORATE)

Comments:

Information source: BOTANIST, MONTANA NATURAL HERITAGE PROGRAM, 1515 EAST SIXTH AVENUE, HELENA, MT 59620-1800.

Specimens: CULWELL, D. AND L. LAARSEN (S.N.) . 1984. SPECIMEN \#353559. RM. 
Scientific Name: PSORALEA HYPOGAEA

Common Name: LITTLE INDIAN BREADROOT

Global rank: G3G4 Forest Service status:

state rank: $\mathrm{SI}$

Federal status:

Element occurrence code: PDFAB5L0C1.002

Element occurrence type:

Survey site name: GREAT FALLS

EO rank:

EO rank comments:

county: CASCADE

USGS quadrangle: UNMAPPABLE

Township: Range: Section: TRS comments:

Precision: U

Survey date: 1886-06-20 Elevation:

First observation: $1886 \quad$ Slope/aspect:

Last observation: 1886-06-20 Size (acres): 0

Location:

GREAT FALLS, MONTANA (HISTORICAL COLLECTION, GENERAL LABEL INFORMATION) •

Element occurrence data:

UNKNOWN .

General site description:

UNKNOWN; "PLAINS AND HILLS" (DORN, 1984).

Land owner/manager:

Comments:

NONE.

Information source: BOTANIST, MONTANA NATURAL HERITAGE PROGRAM, 1515 EAST SIXTH AVENUE, HELENA, MT 59620-1800.

Specimens: ANDERSON, F. W. (S.N.). 1886. NY. 
Scientific Name: PSORALEA HYPOGAEA

Common Name: LITTLE INDIAN BREADROOT

Global rank: G3G4 Forest service status:

State rank: Sl Federal status:

Element occurrence code: PDFAB5L0Cl.003

Element occurrence type:

Survey site name: CHESTNUT VALLEY SANDHILLS

EO rank: C

EO rank comments: TINY POPULATION, GOOD CONDITION HABITAT.

county: CASCADE

USGS quadrangle: NELSON ISLAND

Township: Range: Section: TRS comments:

018N OOIE 21 E2SE4

Precision: $S$

Survey date: 1993-05-24

First observation: 1993-05-24

Last observation: 1993-05-24
Elevation: 3450 -

Slope/aspect: $5 \% / \mathrm{SW}-\mathrm{W}$

size (acres): 1

Location:

SANDHILLS ABOVE CHESTNUT VALLEY ALONG MISSOURI RIVER, CA. 1.5 MILES

EAST AND 3 MILES NNE OF CASCADE, ON THE EAST SIDE OF RIVER ROAD.

Element occurrence data:

7 PLANTS SCATTERED BETWEEN 3 BLOWOUTS SPANNING 0.25 MILE; LOCALLY

RARE. WIDE RANGE IN PLANT VIGOR WHICH MAY CORRESPOND TO AGE. IN PEAK FLOWER 24 MAY 1993.

General site description:

ACTIVE SAND DUNE BLOWOUTS WITH VERY SPARSELY VEGETATED AREAS OF LOOSE

SAND PROVIDE SPECIES' HABITAT. THEY ARE WELL-DEVELOPED, SMALL, NATURAL FEATURES AT MIDSLOPE POSITIONS ON A SANDY RIDGE ABOVE THE MISSOURI RIVER AND THE MOUTH OF BIRD CREEK. ASSOCIATED SPECIES: SPOROBOLUS CRYPTANDRUS, LUPINUS ARGENTEUS, RUMEX VENOSUS, ORYZOPSIS HYMENOIDES, THERMOPSIS RHOMBIFOLIA, CHRYSOPSIS VILLOSA. ONE ADVENTIVE LINARIA DALMATICA PLANT PRESENT (AND PULLED) IN DOWNSLOPE HABITAT; TRACE AMOUNTS OF EUPHORBIA ESULA PRESENT.

Land owner/manager:

PRIVATELY OWNED LAND (INDIVIDUAL OR CORPORATE)

Comments:

SPECIES MAY COMPETE WITH OTHER SAND BLOWOUT LEGUMES, INCLUDING LUPINUS ARGENTEUS AND THERMOPSIS RHOMBIFOLIA. ALL BLOWOUTS IN SECTION 21 AND WEST HALF OF 22 WERE SEARCHED. IMMATURE LUPINUS LOOKS SOMEWHAT LIKE THIS SPECIES AND CONSEQUENTLY A VOUCHER COLLECTION WAS MADE WHEN IT SHOULDN'T HAVE BEEN (DUE TO SMALL POPULATION SIZE). 
MONTANA NATURAL HERITAGE PROGRAM

Element Occurrence Record

Information source: HEIDEL, B. L. 1994. SURVEY FOR PSORALEA HYPOGAEA IN THE GREAT FALLS RESOURCE AREA, LEWISTOWN DISTRICT. UNPUBLISHED REPORT PREPARED FOR THE BUREAU OF LAND MANAGEMENT, MONTANA. MONTANA NATURAL HERITAGE PROGRAM.

Specimens: HEIDEL, B. (1000) . 1993. MONT. 
Scientific Name: PSORALEA HYPOGAEA

Common Name: LITTLE INDIAN BREADROOT

Global rank: G3G4 Forest Service status:

State rank: S1 Federal status:

Element occurrence code: PDFAB5LOC1.004

Element occurrence type:

Survey site name: MISSOURI RIVER BREAKS

EO rank:

EO rank comments:

county: CHOUTEAU

USGS quadrangle: P $\mathrm{N}$ RANCH

Township: Range: Section: TRS comments:

023N O16E 32

Precision: M

Survey date:

First observation: 1990-05-18 Slope/aspect:

Last observation: 1990-05-18 Size (acres):

Location:

ALONG NORTH SIDE OF MISSOURI RIVER, CA. 5 MILES ABOVE JUDITH LANDING.

Element occurrence data:

COMMON.

General site description:

IN SANDY SOIL OF HILIS ALONG NORTH SIDE OF MISSOURI RIVER, WITH

BOUTELOUA GRACILIS AND ASTRAGALUS MISSOURIENSIS.

Land owner/manager:

BLM: LEWISTOWN DISTRICT, HAVRE RESOURCE AREA

PRIVATELY OWNED LAND (INDIVIDUAL OR CORPORATE)

comments:

Information source: LESICA, PETER. DIVISION OF BIOLOGICAL SCIENCES, UNIVERSITY OF MONTANA, MISSOULA, MT 59812.

Specimens: LESICA, P. (5047) AND SCOTT MILES. 1990. SPECIMEN $\# 114545$. MONTU. 
Appendix 3. Printouts of Carex crawei in Montana 
Scientific Name: CAREX CRAWEI

Common Name: CRAW'S SEDGE

Global rank: G5

State rank: S1

Forest Service status:

Federal Status:

Element occurrence code: PMCYP03360.001

Element occurrence type:

Survey site name: TETON RIVER SCHOOL SECTION EO rank:

EO rank comments:

County: TETON

USGS quadrangle: BYNUM RESERVOIR

Township: Range: Section: TRS comments:

025N $007 \mathrm{~W} \quad 36 \quad$ N2

Precision: M

Survey date: -

First observation:

Last observation: 1982

Elevation: 4370 -

Slope/aspect:

Size (acres): 0

Location:

ALONG MARGIN OF SLOUGH OF TETON RIVER (SOUTH OF CANYON RD., ABOUT 5.5

MI. W. OF EUREKA RESERVOIR AND 5 MILES EAST OF PINE BUTTE).

Element occurrence data:

UNCOMMON.

General site description:

ALONG MARGIN OF SLOUGH. WITH CAREX LANUGINOSA AND JUNCUS TENUIS.

Land owner/manager:

PINE BUTTE SWAMP PRESERVE

STATE LAND - UNDESIGNATED

Comments:

Information source: LESICA, PETER. DIVISION OF BIOLOGICAL SCIENCES, UNIVERSITY OF MONTANA, MISSOULA, MT 59812.

Specimens: LESICA, P. (2373). 1982. SPECIMEN \#69002. MONT. 
Scientific Name: CAREX CRAWEI

Common Name: CRAW'S SEDGE

Global rank: G5

State rank: $S 1$

Forest Service status:

Federal status:

Element occurrence code: PMCYP03360.002

Element occurrence type:

Survey site name: EUREKA BORROW PIT

EO rank:

EO rank comments:

county: TETON

USGS quadrangle: BYNUM RESERVOIR

Township: Range: Section: TRS comments:

$025 \mathrm{~N}$ $007 \mathrm{~W}$ 25 SW4

Precision: $M$ Survey date: 1983-

First observation: 1981

Last observation: 1983-

Elevation: 4390 Slope/aspect:

size (acres): 0

Location:

OFF CANYON ROAD, 6 MI. W. OF EUREKA RESERVOIR, N. OF RD.

Element occurrence data:

UNKNOWN.

General site description:

MOIST BORROW PIT, ASSOCIATED WITH CAREX LASIOCARPA, C. AUREA, C. OEDERI, JUNCUS SPP.

Land owner/manager:

PRIVATELY OWNED LAND (INDIVIDUAL OR CORPORATE)

Comments:

FIELD CHECKED BY P. LESICA IN 1983.

Information source: BOTANIST, MONTANA NATURAL HERITAGE PROGRAM, 1515 EAST SIXTH AVENUE, HELENA, MT 59620-1800.

Specimens: LACKSCHEWITZ, K. H. (9686). 1981. MONTU. 
Scientific Name: CAREX CRAWEI

Common Name: CRAW'S SEDGE

Global rank: G5

State rank: SI
Forest Service status:

Federal Status:

Element occurrence code: PMCYP03360.003

Element occurrence type:

Survey site name: BIACKTAIL BENCH (NORTH)

EO rank: A

EO rank comments: LARGE POPULATION, HABITAT IN GOOD-EXCELLENT CONDITION.

County: PONDERA.

USGS quadrangle: FISH LAKE

Township: Range: Section: TRS comments:

029N O1OW 36 SE4, SE4SW4, NE4NE4

Precision: $S$

Survey date: 1988-07-19 Elevation: 4810 -

First observation: 1988

Last observation: 1988-07-19

Slope/aspect:

Size (acres): 200

Location:

BLACKFEET INDIAN RESERVATION, FOOTHILLS OF ROCKY MOUNTAIN FRONT RANGE,

0.3 - 1.1 AIR MILES SOUTH OF BLACKTAIL CREEK, CA. 4 MILES SOUTH OF

HEART BUTTE (TOWN).

Element occurrence data:

1000-2000+ PLANTS, 3 SUBPOPULATIONS NEAR THREE DIFFERENT PONDS.

General site description:

GRAVELLY CALCAREOUS SOILS AROUND PONDS, IN ECOTONE BETWEEN MEADOW AND

DRAWDOWN ZONES; WITH CAREX OEDERI, JUNCUS LONGISTYLIS.

Land owner/manager:

BLACKFEET INDIAN RESERVATION

Comments:

Information source: SHELLY, J. S. 1988. [FIELD SURVEY OF THE BLACKFEET INDIAN RESERVATION OF 18-20 JULY.]

Specimens: SHELLY, J. S. (1491) \& P. LESICA. 1988. MONTU. 
Scientific Name: CAREX CRAWEI

Common Name: CRAW'S SEDGE

Global rank: G5

state rank: $\mathrm{SI}$
Forest Service status:

Federal status:

Element occurrence code: PMCYP03360.004

Element occurrence type:

Survey site name: BLACKTAIL BENCH (SOUTH) EO rank: A

EO rank comments: EXTENSIVE POPULATION, HABITAT IN GOOD-EXCELLENT CONDITION.

County: PONDERA

USGS quadrangle: FISH LAKE

Township: Range: Section: TRS comments:

028N $010 W \quad 02 \quad$ SE4; 1 SW4; 11 NE4; 12 NW4

Precision: $\mathrm{S}$

Survey date: 1988-07-19 Elevation: 4790 -

First observation: 1988

Last observation: 1988-07-19 Size (acres): 150

Location:

BLACKFEET INDIAN RESERVATION, FOOTHILLS OF ROCKY MOUNTAIN FRONT RANGE, 1.85 - 2.5 AIR MILES SOUTH OF BLACKTAIL CREEK, CA. 5 MILES SOUTH OF HEART BUTTE (TOWN).

Element occurrence data:

1000-2000+ PLANTS, SIX SUBPOPULATIONS NEAR FOUR PONDS.

General site description:

GRAVELLY CALCAREOUS SOILS AROUND PONDS, IN ECOTONE BETWEEN MEADOW AND

DRAWDOWN ZONES; WITH CAREX OEDERI, JUNCUS LONGISTYLIS.

Land owner/manager:

BLACKFEET INDIAN RESERVATION

Comments:

Information source: SHELLY, J. S. 1988. [FIELD SURVEY OF THE BLACKFEET INDIAN RESERVATION OF 18-20 JULY.]

Specimens: SHELLY, S. 1988. MONTU. 
Scientific Name: CAREX CRAWEI

Common Name: CRAW'S SEDGE

Global rank: G5

state rank: SI
Forest Service status:

Federal status:

Element occurrence code: PMCYP03360.005

Element occurrence type:

Survey site name: BIG SHEEP MOUNTAIN EO rank:

EO rank comments:

County: PRAIRIE

USGS quadrangle: BIG SHEEP MOUNTAIN

Township: Range: Section: TRS comments: 015N 048E 29 NW4SE4

precision: $S$

Survey date: Elevation: 3280 -

First observation: 1992-06-12 Slope/aspect: $4 \%$ / NNE

Last observation: 1992-06-12 Size (acres): 1

Location:

FROM TERRY TRAVEL 22.7 MILES NORTHWEST ON THE ROAD TOWARD BROCKWAY, THEN TURN WEST ON BIG SHEEP MOUNTAIN ROAD AND TRAVEL CA. 3 MILES. SITE IS 0.7 MILE SOUTH.

Element occurrence data:

POSSIBLY 2 SUBPOPULATIONS, FLOWERING AND FRUITING.

General site description:

ROLLING UPLANDS, PARTIAL SHADE, SATURATED UPPER SLOPE. CALCAREOUS

SILTY CLAY SOIL. ASSOCIATED SPECIES: CAREX AUREA, GLYCERIA STRIATA,

CAREX LANGUINOSA, CAREX INTERIOR, LYCOPUS AMERICANUS, JUNCUS BALTICUS.

Land owner/manager:

BLM: MILES CITY DISTRICT, BIG DRY RESOURCE AREA

Comments:

OBSERVED BY L. ROE AND P. HARRINGTON. SITE NEEDS TO BE REVISITED TO DETERMINE POPULATION EXTENT AND REPRODUCTIVE SUCCESS.

Information source: BOTANIST, MONTANA NATURAL HERITAGE PROGRAM, 1515 EAST SIXTH AVENUE, HELENA, MT 59620-1800.

Specimens: ROE, L. (489). 1992. MONT. 
MONTANA NATURAL HERITAGE PROGRAM

Element Occurrence Record

Scientific Name: CAREX CRAWEI

Common Name: CRAW'S SEDGE

Global rank: G5 Forest Service status:

State rank: Sl Federal Status:

Element occurrence code: PMCYP03360.006

Element occurrence type:

Survey site name: CHESTNUT VALLEY SANDHILLS

EO rank: B

EO rank comments: LIMITED EXTENT, GOOD CONDITION HABITAT.

County: CASCADE

USGS quadrangle: NELSON ISLAND

Township: Range: Section: TRS comments:

018N OO1E $28 \quad$ NE4NW4

Precision: $S$

Survey date: 1993-07-06 Elevation: 3370 -

First observation: 1993-07-06 Slope/aspect:

Last observation: 1993-07-06 Size (acres): 2

Location:

SANDHILLS ABOVE CHESTNUT VALLEY ALONG MISSOURI RIVER. FROM CASCADE GO 1.5 MILES EAST AND 2.5 MILES NNE; SITE IS JUST BEYOND BIRD CREEK CROSSING ON THE SOUTH SIDE OF THE RIVER ROAD.

Element occurrence data:

COMMON IN AREAS WITH OPEN MARL POOLS.

General site description:

MARL MEADOW PROVIDES SPECIES' HABITAT, IN ONE BASIN AMONG MANY

SANDPLAIN SWALES HAVING OTHER WETLAND TYPES, AMONG ROLLING SANDHILLS. LOCAL DOMINANTS ARE CALAMAGROSTIS INEXPANSA AND JUNCUS BALTICUS. ASSOCIATED SPECIES: CAREX PARRYANA, C. AUREA, ELEOCHARIS COMPRESSA, MUHLENBERGIA RICHARDSONIS.

Land owner/manager:

BLM: LEWISTOWN DISTRICT, GREAT FALLS RESOURCE AREA

Comments:

SPECIES IS RECOMMENDED ADDITION TO BLM SENSITIVE SPECIES LIST; OCCURS ON BLM TRACT SLATED FOR DISPOSAL.

Information source: HEIDEL, B. L. 1994. SURVEY FOR PSORALEA HYPOGAEA IN THE GREAT FALLS RESOURCE AREA, LEWISTOWN DISTRICT. UNPUBLISHED REPORT PREPARED FOR THE BUREAU OF LAND MANAGEMENT, MONTANA. MONTANA NATURAL HERITAGE PROGRAM. [IN PROGRESS]

Specimens: HEIDEL, B. (1105). 1993. MONT, MICH. ! A. A. REZNICEK. 
Appendix 4. Natural Areas Site information

BLM Tract \#22, R. H. Jones lease in Chestnut Valley sandhills

General location: Northeast of Cascade at the edge of the Missouri River valley near its confluence with Bird creek, along an unusually sandy segment of the Missouri River Valley referred to as the Chestnut Valley. A map showing location accompanies this text.

Directions: From the town of Cascade, about 1.5 miles east and 3 miles north-northeast by "River Road", above east side of Missouri River. Located to the east of River Road, north of Bird creek crossing.

county: Cascade

USGS Quad: Nelson Island (4711135)

Legal description: T.18N RIE Sec. 28 NE $1 / 4$ of $\mathrm{NW} 1 / 4$

Size: Boundaries have not been drawn. Survey was focused on the 40 acre BLM tract, which is apparently fenced along its north and east margins. There was no delimitation of its southern and western boundaries. Excellent condition habitat appears to extend to the north, east and south. Boundary delimitation of intact landscape as protection target should be pursued using aerial photographs, involving landowner contacts.

Site description: BLM Tract \#22 lies within gently rolling sandplains that form a mosaic of sandhills and swales between them. The varied topography and associated zonations represent a high concentration of habitat diversity with intact hydrological gradients. To the north lies a high ridge of loose sand.

Within this area are springs and seeps that increase the aquatic diversity of associated swale meadow and marsh habitats. There is a range of fresh to brackish water; the trace amounts of alkali-tolerant vegetation present reflect limited influence of alkalinity from the underlying bedrock. Also within this area are natural sand blowouts which represent extremely xeric, earlysuccessional conditions.

It lies in a scenic setting above the Missouri River near its confluence with Bird Creek, where there is interesting, albeit degraded, oxbow and streamside thicket habitat.

$\begin{array}{llll}\text { Elements: } & \text { GRANK } & \text { SRANK } & \text { EORANK } \\ \text { 1. Psoralea hypogaea } & \text { G3G4 } & \text { S1 } & \text { C } \\ \text { Carex crawei } & \text { G5 } & \text { S1 } & \text { B }\end{array}$

Terrestrial and palustrine plant communities were not identified for purpose of this study, but noteworthy habitat condition and 
diversity suggests that they warrant further investigation. plant community values may actually constitute the highest biodiversity site values.

other comments: Snake and frog observations were made for MTHP herps project; other animal information is wanting.

Land use: Livestock grazing in multi-pasture rotation.

Rey environmental factors: The landscape is shaped by the forces of water and wind. Chestnut valley represents a periglacial delta deposit where the Missouri River emptied into glacial Lake Great Falls. The sandy delta deposits have been reworked by the wind, most markedly in the area of BLM Tract \#22, constituting a mosaic of wetlands and rolling sandhills. Wind is the primary agent causing active sand blowouts at present.

Blowout development occurs mainly on the sandy ridge at the north end of the area. The one major blowout on or near BLM Tract \#22 appears to be natural in origin but exacerbated by livestock use patterns.

Underground water movement in this area affects the site, particularly at springs and the one seepage-fed basin in the area that has marl deposit.

Exotics: The area is notably free of noxious weeds, but is vulnerable. Three waif plants of Dalmatian toadflax (Linaria dalmatica) were found and pulled. Leafy spurge (Euphorbia esula) was found in very low numbers at a single site, the largest sand blowout, with little indian breadroot at the same blowout. Exotic species are asterisked in the species list at the end of this site summary.

Protection comments: BLM Tract \#22 is being considered for disposal pending environmental assessment.

Cultural features: A possible tipi ring pattern was noted near the top of a ridge above blowouts. Blowouts elsewhere in the state have archeological significance.

Management needs: Information on the pasture rotation of BLM tract \#22 and the adjoining tract with little indian breadroot should be documented and considered in any management planning.

Further investigation into hydrology may also be warranted. Deep roadside ditches probably have small affect. There are no stock dams in the area, but one of the springs in the area that wasn't checked may have been developed as a dugout. No central pivot irrigation was noticed in vicinity.

Discussion summary: This site warrants special attention by the BLM Great Falls Resource Area office, which is central in determining and pursuing any conservation action. 


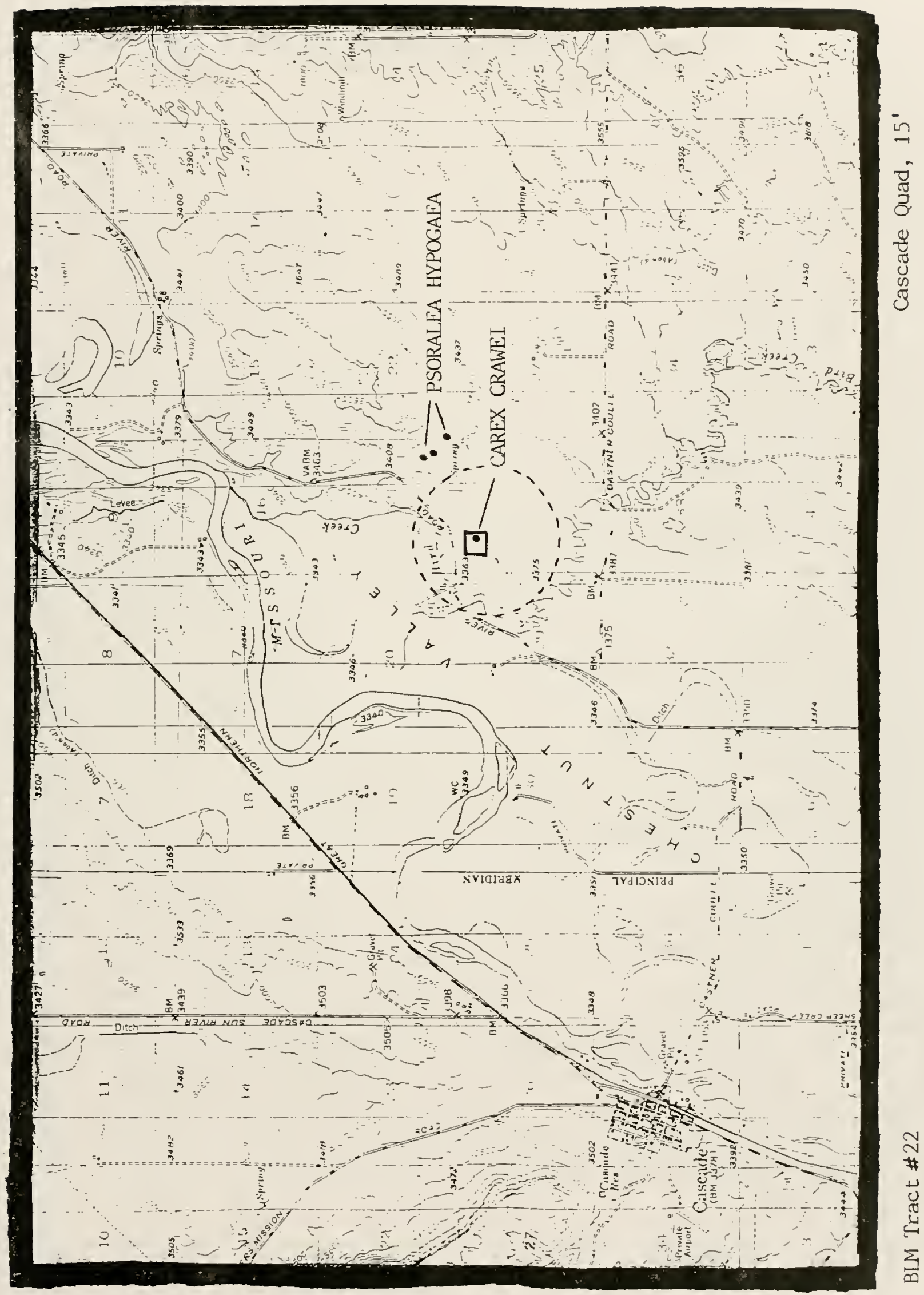


Preliminary list of vascular plants

BLM Tract \#22 and surroundings

Agastache urticifolia

Agropyron smithii

Agropyron trachycaulum

Apocynum sp.

Alisma spp.

Allium textile

Antennaria microphylla

Artemisia biennis

Artemisia campestris

Artemisia frigida

Andropogon scoparius

Aster ericoides

Astragalus goniatus

Astragalus missouriensis

Boutleoua gracilis

Bromus pumpellianus

Bromus tectorum*

Calamagrosis inexpansa

Campanula rotundifolia

Carex aurea

Carex crawei

Carex douglasii

Carex lanuginosa

Carex parryana ssp. parryana

Carex stenophylla

Chenopodium leptophyllum

Chrysopsis villosa

Cirsium arvense*

Crepis spp.

Cymopteris spp.

Cynoglossum officinale*

Descurainia pinnata*

Draba reptans

Distichlis stricta

Eleocharis compressa

Eleocharis pauciflora

Elymus canadensis

Equisetum laevigatum

Equisetum varietagum

Erigeron spp. (lonchophyllus?)

Erysimum reptans

Euphorbia esula*

Festuca octoflora*

Festuca ovina

Glyceria striata

Glycyrrhiza lepidota

Hordeum jubatum

Habenaria hyperborea

Iris missouriensis 
Preliminary list of vascular plants

BLM Tract \#22 and suroundings

Juncus balticus

Juncus bufonis

Juncus spp (castanea?)

Juncus drummonndii

Juncus longistylis

Koeleria cristata

Lesquerella ludoviciana

Lithospermum arvense

Lithospermum incisum

Lupinus argenteus

Lycopus sp.

Lygodesmia juncea

Muhlenbergia richardsonis

Opuntia fragilis

opuntia polyacantha

Orobanche ludoviciana

oryzopsis hymenoides

oxytropis sericea

Penstemon albidus

Penstemon spp.

Poa compressa*

Poa secunda

Polygonum douglasii

Potentilla anserina

Potentilla concinna

Psoralea hypogaea

Ranunculus cymbalaria

Rosa arkansana

Rumex venosus

Salix spp.

Salsola kali*

Scirpus acutus

Scirpus americanus

Scirpus pungens

setaria viridis

Shepherdia argentea

Sisyrinchium montanum

Solidago canadensis

Solidago rigida

Spartina sp. (gracilis?)

sporobolus cryptandrus

Themopsis rhombifolia

Toxicodendron rydbergii

Vicia americana

Viola spp.

Yucca glauca 


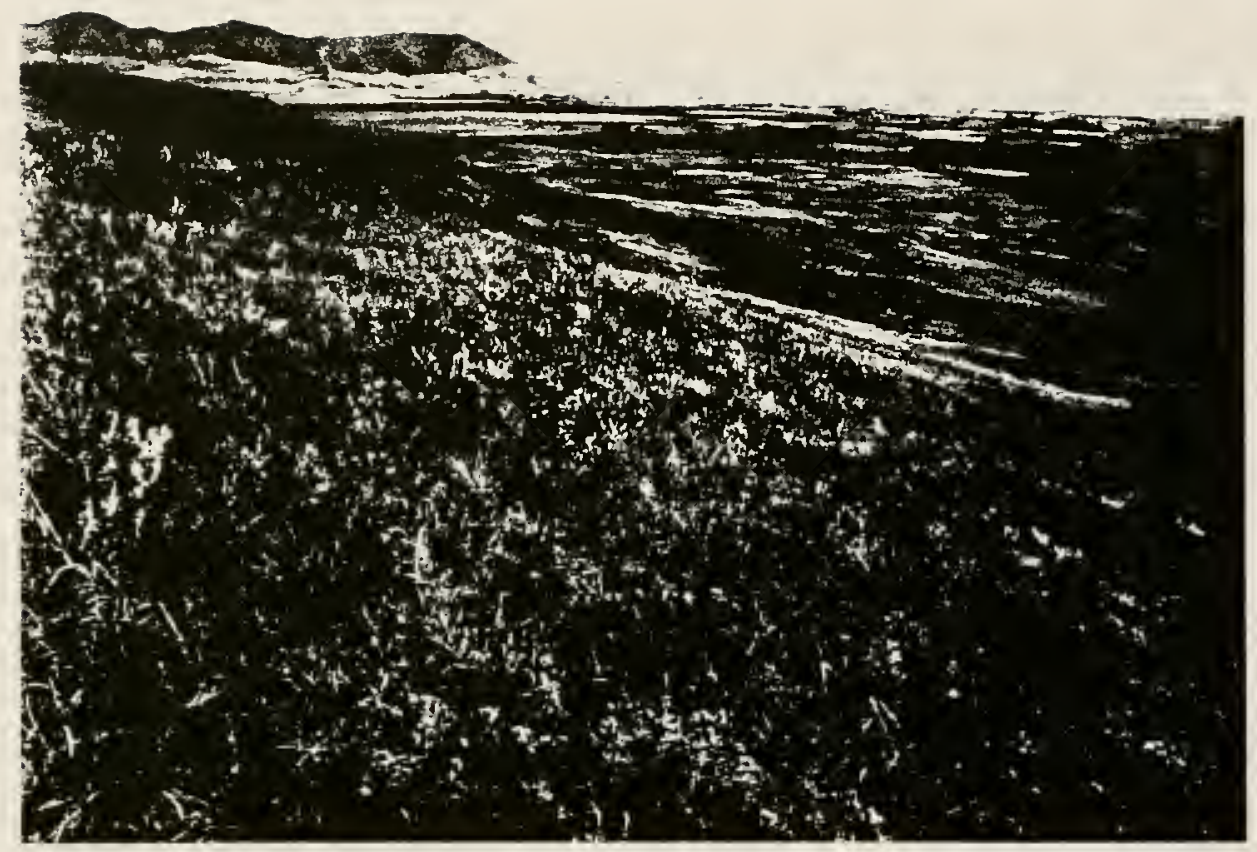

Figure 4. General aspect of BLM Tract \#22, looking across it from adjoining sandy ridge which harbors Psoralea hypogaea

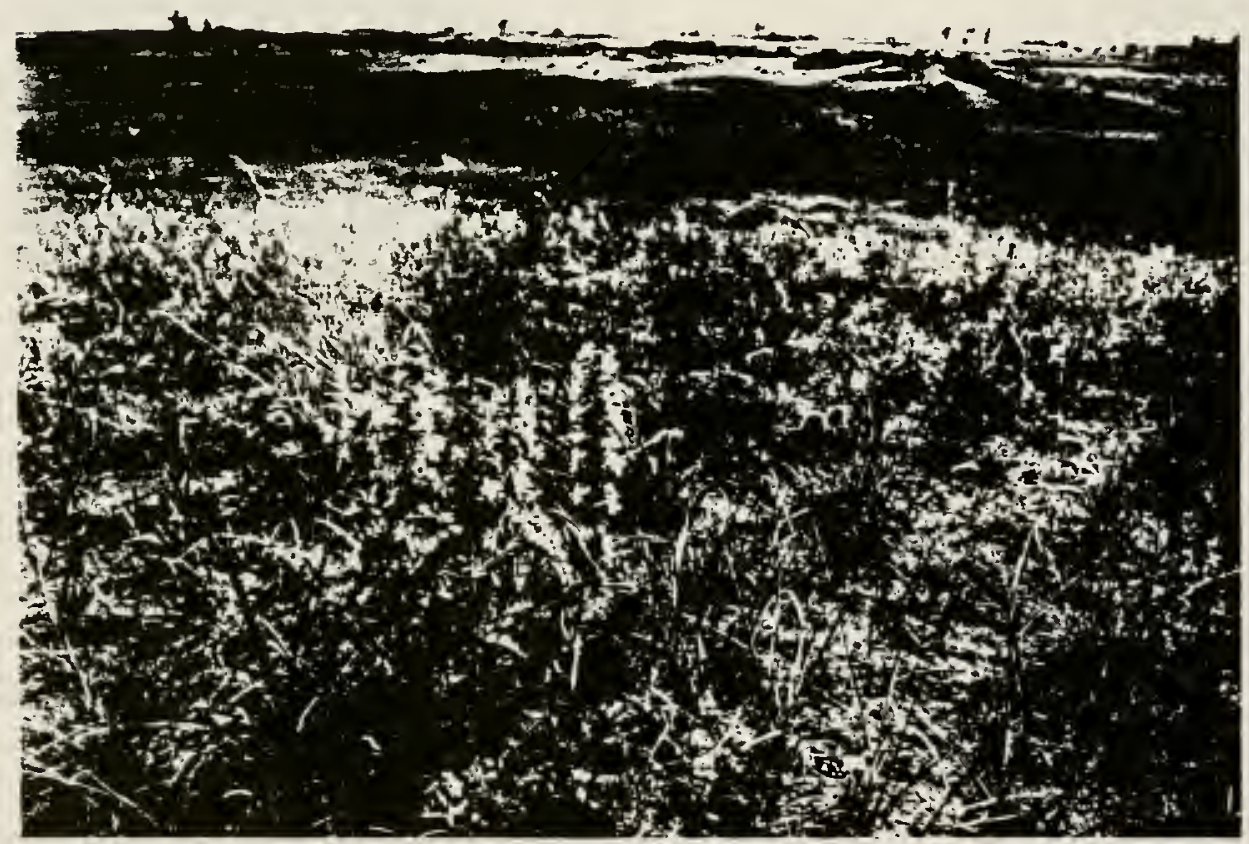

Figure 5. Rolling sand prairie vegetation of BLM Tract \#22, dominated by prairie sandreed (Calomovilfa longifolia) and with a diversity of psammophilic (sand-loving) plants 


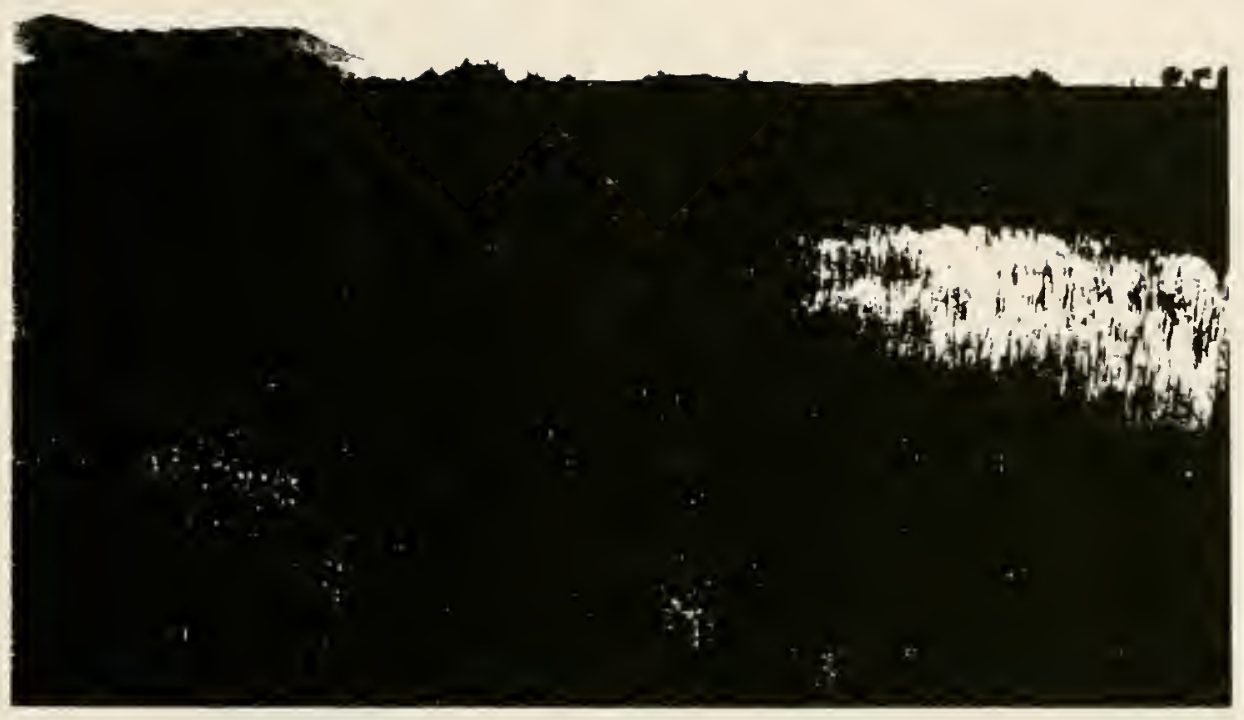

Figure 6. Wetland swale vegetation of BLM Tract \#22, representing the most locally common "ephemeral wetland" type, in a highwater year 
